\title{
The Effect of Mind Map Integration in the Problem Based Learning Model on Creative Thinking of VIII Class Students
}

\author{
Utharia Darmayanti $^{1,2} *$, Sri Wulandari ${ }^{2}$, Fitra Suzanti ${ }^{2}$ \\ ${ }^{1}$ Pondok Pesantren Darul Fatah, Sendayan, Kampar Utara, 28469, Indonesia \\ ${ }^{2}$ Postgraduate Biology Education Master Program, University of Riau Pekanbaru 28293
}

\section{ARTICLE INFO}

\section{Article history:}

Received: 18 Nov 2020

Revised: 28 June 2021

Accepted: 02 July 2021

Published online: 24 July 2021

Keywords:

Creative Thinking

Mind Map

Problem Based Learning

\begin{abstract}
A B S T R A C T
The 2013 curriculum requires teachers to integrate higherorder thinking skills. One of them is creative thinking. Mind map integration in Problem Based Learning (PBL) is thought to be able to assist students in improving creative thinking. This study aims to determine the effect of increasing creative thinking through the integration of mind maps in PBL on eighth grade students of SMPN 25 Pekanbaru. This type of research is quasi-experimental. The research population was class VIII SMPN 25 Pekanbaru. The research sample consisted of class VIII.1 as the experimental class and class VIII.2 as the control class. Data in the form of pretest and posttest. N-gain analysis was conducted to see the increase in student scores and MANOVA was used to examine the effect of mind maps in PBL on students creative thinking abilities. The average value of creative thinking is better in the experimental class which is 78.08 in the digestive system material with $\mathrm{N}$-gain relatively close to high, namely 0.68 while in the control class only 54.88 is sufficient category. The MANOVA test also shows that there is an effect of mind maps in PBL on the creative thinking ability of class VIII SMPN 25 Pekanbaru with a significance value of $0.000<0.05$. This shows that the application of mind map integration to PBL is able to improve the creative thinking skills of SMP Negeri 25 Pekanbaru students.
\end{abstract}

\section{Introduction}

Education is a process of motivating students to be able to adapt to their environment which will cause changes in themselves in social life. The purpose of education is to shape a person to be qualified, have character and have a broad view of the future and be able to adapt quickly and precisely in various aspects of life (Hamalik, 2017). 
The 2013 curriculum requires teachers to integrate higher-order thinking skills into the learning process, especially for junior high school students (Kemendikbud, 2017). One of the higher order thinking that can be developed is creative thinking. The ability to think creatively is very important to form a structured mindset so that students are able to master concepts, analyze problems and solve problems that exist in everyday life (Husen, 2016).

An innovative learning model in the learning process that solves a problem is the Problem Based Learning model. According to Fathurrohman (2015), the main principle of PBL is the use of real problems as a means for students to develop knowledge and at the same time develop creative thinking and problem solving abilities. The problem is a problem that exists in everyday life and is immediately useful when solved. In line with research (Handoyo et al., 2021) of course, problem-based learning can build students' thinking skills. Hasanah (2010) also states that one way for students to easily master the concept is by actively involving students in learning. Learning with PBL will be more effective if it is combined with a mind map in the learning stages. Mind maps are a way of taking creative notes by capturing various thoughts that are carried out in accordance with the natural workings of the two brains synergistically (Windura, 2013). Mind maps can help students determine and arrange the important points of the subject matter because using a mind map will make it easier for students to make conclusions and remember the material they have learned. Therefore, the integration of the mind map with the PBL model used is expected to improve students' creative thinking skills.

\section{Methodology}

This research was a quasi-experimental study with a pretest-posttest control group design. The study population was all class VIII SMPN 25 Pekanbaru. The research sample consisted of 2 classes consisting of the experimental class (VIII.1) totaling 39 people and the control class (VIII.2) totaling 42 students. The research was conducted in the 2019/2020 school year from November 14 to December 12, 2019. Two variables were used in this study, namely the independent variable and the dependent variable. The independent variables in this study were the conventional learning method in the control class and the mind map learning model in PBL in the experimental class, while the dependent variable was the mastery of concepts and creative thinking as a result of the treatment of the independent variables. In this study, the material of the digestive system in humans was used.

In this research, collecting data ws done by giving a pretest before learning to the students for both classes. Then, subsequently we were carrying out a posttest to evaluate learning outcomes, namely creative thinking in the experimental and control classes. Twenty multiple choice questions were used to assess the students' creative thinking level. Data analysis was carried out on the creative thinking ability test scores descriptively and manova. Descriptive analysis is used to 
analyze data on creative thinking skills. MANOVA analysis was used to test the hypothesis.

\section{Results and Discussion}

This research begins with conducting analysis. The analysis carried out is an analysis of the ability to think creatively in Biology Science by Integrating Mind Map in Problem Based Learning Class VIII SMPN 25 Pekanbaru and the influence of mind maps in problem based learning on increasing students' creative thinking skills.

\section{Analysis of Cognitive Ability to Think Creatively Science Biology by Integrating Mand Map in Problem Based Learning in Class VIII SMP N 25 Pekanbaru}

Creative thinking ability is measured by pretest and posttest questions with 20 multiple choice questions from four indicators, namely Fluency and Flexibility each given seven multiple choice questions, Originality is given one multiple choice question, and Elaboration is given five multiple choice questions. Overall, it shows that there is an increase in the creative thinking of the experimental class (VIII.1) students who use the PBL learning method with the help of a mind map better than the control class (VIII.2) with conventional learning methods. There is an increase in the value of creative thinking from the pretest and posttest in the experimental class and also the control class. However, the increase in the average score of students in the experimental class was better, increasing from $30.13 \%$ to $78.08 \%$ in the digestive system. While the control class only experienced an average increase from $29.05 \%$ to $54.88 \%$ in the digestive system material as shown in table 1.

Table 1. Average Value of Creative Thinking by Integrating Mand Map in Problem Based Learning in Class VIII SMP N 25 Pekanbaru

\begin{tabular}{ccccc}
\hline \multirow{2}{*}{ Indicator } & \multicolumn{4}{c}{ KD. 3.5 Sistem Pencernaan } \\
\cline { 2 - 5 } & Experiment Class & Control Class \\
\cline { 2 - 5 } & Pretest & Postest & Pretest & Postest \\
\hline Fluency thinking ability (Fluency) & 25,64 & 75,64 & 34,13 & 57,94 \\
Flexible Thinking Ability (Flexibility) & 31,50 & 80,22 & 25,51 & 50,00 \\
Ability to think original (Originality) & 23,08 & 74,36 & 30,95 & 47,62 \\
Detailed thinking skills (Elaboration) & 30,77 & 76,41 & 23,33 & 59,05 \\
\hline Total Average & 27,75 & 76,66 & 28,48 & 53,65 \\
\hline Category & KS & B & KS & C \\
\hline
\end{tabular}

The results of the $\mathrm{N}$-gain analysis also showed that the scores of the experimental class students increased with a category close to high, namely 0.68 on the human digestive system material, in the control class the increase in scores was still in the low category, namely 0.17 on the digestive system material. The same result was also expressed by (Sumarta, 2017) that PBL with the help of mind maps was able 
to improve creative thinking skills in learning biology in students compared to conventional learning methods in the control class.

\section{The effect of mind maps in problem based learning (PBL) on increasing students' creative thinking skills}

Data analysis carried out at this stage is the analysis of the results before treatment and after treatment. The data obtained before and after the treatment included students' creative thinking data for both the experimental class and the control class. The results of the Multivariate Analysis of Variance (MANOVA) statistical test can be seen in table 2 .

Table 2. The results of the Multivariate Analysis of Variance (MANOVA) statistical test for the creative thinking ability of eighth grade students of SMPN 25 Pekanbaru

\begin{tabular}{|c|c|c|c|c|c|c|}
\hline \multicolumn{7}{|c|}{ Multivariate Tests $^{\mathrm{a}}$} \\
\hline & Effect & Value & $\mathrm{F}$ & Hypothesis df & Error df & Sig. \\
\hline \multirow[t]{5}{*}{ Intercept } & Pillai's Trace & .990 & $3878.314^{\mathrm{a}}$ & 2.000 & 78.000 & .000 \\
\hline & Wilks' Lambda & .010 & $3878.314^{\mathrm{a}}$ & 2.000 & 78.000 & .000 \\
\hline & Hotelling's Trace & 99.444 & $3878.314^{\mathrm{a}}$ & 2.000 & 78.000 & .000 \\
\hline & Largest & 99.444 & $3878.314^{\mathrm{a}}$ & 2.000 & 78.000 & .000 \\
\hline & Root & & & & & \\
\hline \multicolumn{7}{|c|}{ Multivariate Tests ${ }^{\mathrm{b}}$} \\
\hline & Effect & Value & $\mathrm{F}$ & Hypothesis df & Error df & Sig. \\
\hline \multirow[t]{5}{*}{ Kelas } & Pillai's Trace & .660 & $75.812^{b}$ & 2.000 & 78.000 & .000 \\
\hline & Wilks' Lambda & .340 & $75.812^{b}$ & 2.000 & 78.000 & .000 \\
\hline & Hotelling's Trace & 1.944 & $75.812^{b}$ & 2.000 & 78.000 & .000 \\
\hline & Largest & 1.944 & $75.812^{b}$ & 2.000 & 78.000 & .000 \\
\hline & Root & & & & & \\
\hline
\end{tabular}

MANOVA results show a significant result of 0.000 meaning $<0.05$, reject $\mathrm{H} 0$ and accept $\mathrm{H} 1$ (the researcher's hypothesis is accepted). This shows that there is an influence of mind map integration in the PBL model on increasing the creative thinking ability of eighth grade students of SMP Negeri 25 Pekanbaru. Similar results were also stated by (Hanim et al., 2020) from the results of the analysis there was an influence of mind maps in PBL on the mastery of concepts and scientific literacy of junior high school students. Sumarta (2017) also explained that PBL assisted by mind maps was able to improve creative thinking skills and biology learning outcomes for students of SMK Negeri 1 Kubucepatan. This is because PBL helps students to master science concepts scientifically by involving students to ask questions related to daily life problems with the help of mind maps in PBL students are taught how to construct knowledge on a problem so that in addition to increasing mastery of concepts, it also improves students' ability to think creatively. The application of Mind maps in PBL guides students to connect 
material and student experiences in daily life so that students are able to express ideas and concepts according to the problems studied (Long et al., 2011). Mind maps guide students to have spoken and written language so that students can see, read, imagine and improve students' creative thinking skills. Mind maps are also a visual representation of thoughts so that they help create ideas for understanding a concept and solving problems in their own way based on existing problems (Long et al., 2011). Thus the mind map in the PBL learning process provides students with the breadth of thinking in accepting and understanding a material presented by the teacher so as to increase the value of mastery of concepts and also increase students' creative thinking power.

\section{Conclusion}

Based on the research that has been done, it can be concluded that the Mind map in the Problem Based Learning model affects the ability to think creatively. Analysis of the data from the MANOVA test results showed that there was an effect of mind maps in PBL on increasing creative thinking skills for class VIII SMPN 25 Pekanbaru with a significance value of $0.000<0.05$ which consisted of indicators of Fluency, Flexibility, Originality and Elaboration.

\section{Acknowledgment}

Thanks to Mrs. Sri Wulandari, M.Si, Mrs. Dr. Fitra Suzanti, M.Si, Mrs. Dr. Evi Suryawati, M.Pd and Mrs. Dr.Ir. Zulfarina, M.Si who has guided and provided direction in the research that has been carried out.

\section{References}

Fathurrohman, M., 2015. Model-Model Pembelajaran Universitas Negeri Yogyakarta. Jogjakarta : Ar-Ruzz Media.

Hamalik, O. (2017). Proses Belajar Mengajar. Jakarta: Bumi Aksara.

Handoyo, R. F., Rosbiono, M., \& Sopandi, W. (2021). Building Students' Creative Thinking Skills Using Problem-Based Learning in Handling Staple Food Waste. Journal of Educational Sciences, 5(1), 89-103.

Hanim, L., Susilo, H., \& Yuliati, L. (2020). Pengaruh Peta Pemikiran dalam Pembelajaran Berbasis Masalah terhadap Penguasaan Konsep dan Literasi Sains Siswa SMP. Jurnal Pendidikan: Teori, Penelitian, dan Pengembangan, 5(2), 180-186.

Hasanah, I., 2010, Pengaruh Metode SQ3R Terhadap Kemampuan Pemahaman Kosep Matematika. Skripsi. Fakultas Ilmu Tarbiah dan Keguruan Universitas Islam Negeri Syarif Hidayatullah, Jakarta.

Husen, D. N. (2016). Peningkatan kemampuan berpikir kreatif siswa melalui penerapan model problem based learning. BIOEDUKASI, 3(2).

Kementerian Pendidikan dan Kebudayaan (Kemendikbud), 2017. Panduan Penilaian Oleh Pendidik Dan Satuan Pendidikan sekolah menengah 
pertama. Kementrian pendidikan dan kebudayaan Direktorat Jendreal Pendidikan Dasar dan Menegah Direktorat Pembinaan Sekolah Menengah Pertama, Jakarta.

Long, D. J., \& Carlson, D. (2011). Mind the map: How thinking maps affect student achievement. Networks: An Online Journal for Teacher Research, 13(2), 262-262.

Sumarta,, I. G. B., 2017. Pengaruh Pembelajaran Berbasis Masalah Berbantuan Mind Map terhadap Keterampilan Berpikir Kreatif dan Hasil Belajar Biologi pada Siswa SMK. Jurnal Imiah Pendidikan dan Pembelajaran, 1(1), 2615-6091.

Windura, S., 2013. MIND MAP Teknik Berpikir \& Belajar Sesuai Cara Kerja Alami Otak. Jakarta : Gramedia.

How to cite this article:

Darmayanti, U., Wulandari, S., \& Suzanti, F. (2021). The Effect of Mind Map Integration in the Problem based Learning Model on Creative Thinking of VIII Class Students. Journal of Educational Sciences, 5(3), 417-422. 